\title{
Compliance with the 2008 Fire Code of The Philippines (RA 9514): Basis for Intervention
}

\author{
Jhon Louie A. Pintac, Diomedes R. Pechora, Victoria O. Ligan \\ Professional Schools, The University of Mindanao, Davao City-Philippines
}

\begin{abstract}
This research intended to establish the extent of citizen's compliance with Republic Act 9514-the 2008 Fire Code of the Philippines, and introduce intervention strategies for its implementation. The study was a univariate-descriptive approach that utilized secondary data, a consolidated accomplishment report on fire safety evaluation and inspection by the fire stations in Davao City from 2016 to 2018. A total of 115,089 data were analyzed using descriptive statistics to realize the objectives of the study. Results showed that only the business and mercantile structure owners have the highest percentage of compliance at about 45 percent, compared to the rest of the structure owners. Moreover, the data exposed a decreasing trend in the Fire Safety Inspection Certificates (FSIC) issuances from 2016 to 2018 , which suggested that more and more building owners did not comply with the fire code every year. Overall, the data implied a high risk of fire occurrences in the city, considering the high percentage of non-compliance with the fire code. Hence, the researcher calls for adopting the proposed intervention strategies recommended in this study to optimize compliance with RA 9514.
\end{abstract}

Keywords: public administration, RA 9514, Fire Code of the Philippines, compliance, Bureau of Fire Protection

\section{INTRODUCTION}

$\mathrm{N}$ on-compliance to the Philippines' Fire Code of 2008 resulted in the loss of thousands of lives and billions of properties. As an elaboration, an electrical short circuit burned down the NCCC mall in Davao City on December 23, 2017, and claimed 38 lives (Antonio IV, 2018; Basa, 2017 Colina, 2018; Revita, 2018; Nawal \& Lim, 2017; Villamor, 2017a; 2017b). Likewise, on May 13, 2015, a fire broke out at the Kentex Manufacturing factory in Valenzuela City and claimed 74 lives. The worst fire recorded in the Philippines was the 1996 Ozone Disco Club fire that claimed 162 lives (Bautista, 2017; Mayuga, 2018). These are just a few examples of morbid fire incidents. All of these happened due to the very poor or even non-compliance of the fire code.

Following the Fire Code of 2008 is of extreme importance when erecting buildings, structures, and facilities. This code has laid the frameworks for the building code or the fire safety compliance in buildings. So, all structure owners should be mindful of the importance of complying with the building code as the fire was the sixth leading cause of unintentional injury-related death over all ages in 2017 (National Safety Council, 2020). Fires often start at night, and if buildings are compliant with the fire code, a working smoke alarm will give sleeping families more than half a chance of survival (National Safety Council, 2018; William Hird \& Company, 2020).

In the Philippines, the Bureau of Fire Protection has launched fire awareness programs all over the country, with the theme, "Ligtas Na Pilipinas Ang AtingHangad, Pag-Iingat Sa Sunog Sa SariliIpatupad," (We Aim for a Safe Philippines, Observe Fire Safety). Besides this, the BFP has programs and activities that would reduce fire incidents in the country. They also have brochures that would guide in preventing injuries and save lives (Philippine Primer, 2018). Similarly, in Davao City, the BFP has several campaign activities for fire safety and prevention. They have been campaigning in public and private schools to raise awareness among students; fire drills conclude them (Opiana, 2017).

Sadly, although the BFP has these activities, the researcher did not find a study investigating compliance with the Republic Act 9514 in the local setting. Thus, the researcher inquired into this topic with the following objectives to propose an intervention program based on the findings:

1. To assess the percentage of compliance with RA 9514 or the Philippines' Fire Code, vis-à-vis applications for FSIC, from 2016 to 2018.

2. To compare the Fire Safety Inspection Certificate (FSIC) issuances from 2016 to 2018.

3. To design intervention strategies for effective implementation and compliance with RA 9514 based on the study's findings.

\section{LITERATURE REVIEW}

\subsection{The Significance of Fire Codes and Fire Regulations}

Countries all over the world always have fire codes for fire prevention. In the United States, they have the National Fire Protection Association (NFPA), an international organization that advances the public and the responders' safety. It provides a comprehensive, integrated approach to fire code regulation and hazard management extracted from more than 130 NFPA codes and standards, including industry benchmarks (NFPA, 2019). In America, fires are not only the concern of one agency. The American Red Cross, for instance, has launched the "Home Fire Campaign" to reduce death and injury from home fires by $25 \%$ (American Red Cross, 2019). 
In Canada, they have the National Fire Code of Canada 2015 (NFC) that sets out the provisions regulating the use, construction, and demolition of buildings and facilities. It sets the conditions and specifics of buildings and facilities related to the protection measures from particular hazards. The NFC 2015 complements the National Building Code of Canada 2015, which becomes the guidelines for constructing, renovating, or maintaining buildings in Canada (Government of Canada, 2019).

In England and Wales, there is the Regulatory Reform Order (Fire Safety Order) 2005, in which business owners will comply to avoid penalties such as fines and or imprisonment. Not only this, but all owners of buildings must undergo a Fire Risk Assessment also, identifying the risks and hazards in commercial premises before they could start their construction (Fire Risk U.K. Limited, 2018; London Fire Brigade, 2019).

In France, the Code of Housing and Construction, the Labour Code, and specific laws are the basis for Fire regulation. Fire safety regulation is a set of local and European standards and decrees as E.U. directives are gradually getting integrated at the national and local levels. They have centralized fire prevention competencies observed by different ministries like the Interior, Housing, Labor, Environment, and Equipment ministries. These various agencies set the minimum compliance requirements for the design, construction, and buildings management that prevent fires and ensure safety (CFPE Europe, 2019).

In Australia, they established the Building Code of Australia (BCA) that guides building designs and other structures, defining structural adequacy including building fire resistance, and provisions for the health and amenity of occupants among others (Government of Australia, 2020). Moreover, in addition to the BCA, the Australian Building Codes Board has looked into the possible deviations to energy efficiency provisions, especially on residential buildings, dubbed as the National Construction Code 2022 (Australian Building Codes Board, 2019).

In New Zealand, they have the Building Act of 2004 that laid down the Building Code. The Building Consent Authorities (BCA) ensures that all building constructions are compliant with the Building Code even if the structure does not require a building permit. The BCA's move is necessary to guarantee the occupants' safety and health (Ministry of Business, Innovation, \& Employment, 2020).

In the Philippines, the RA 9514, known as the Fire Code of the Philippines of 2008, lays down the building code's foundation for public safety.

\subsection{Fire Code of the Philippines 2008 (RA 9514)}

Republic Act 9514 established the Philippines' comprehensive fire code and repealed P.D. No. 1185, series of 1977. It reiterates the State's policy of ensuring public safety and promoting economic growth by preventing and suppressing all kinds of destructive fires. It also professionalizes the fire service as a profession. To achieve these, the State has enforced laws, rules, and regulations to ensure adherence to fire safety and prevention measures and promote accountability in the fire protection and prevention service (Republic Act No. 9514, sec. 2).

Additionally, RA 9514 is practically a litany of the fire safety measures required when erecting building structures, as well as the penalties for violations of the code. Hence, discussions about fire safety measures become essential as they are the parameters for the BFP's inspection, approval, and issuance of the Fire Safety Inspection Certificate (FSIC).

\subsection{Fire Safety Measures for Fire Safety Inspection Certification (FSIC)}

Completing the fire safety measures is a requirement for the Fire Safety Inspection Certificate (FSIC); otherwise, the building construction cannot proceed. The fire safety measures cover buildings, structures and facilities, hazardous operations and processes, and miscellaneous unsafe premises and conditions that pose a threat or danger to life, property, and environment (Rule 10, Chapter 1 Implementing Rules \& Regulations of RA 9514). RA 9514 classifies building structures into the assembly, educational, health care, detention and correctional, residential, mercantile, business, industrial, storage, mixed occupancies, and various (miscellaneous) occupancies. All these structures shall pass the fire safety standards before they can be issued FSIC.

\subsection{Fire Safety Awareness and Prevention as a Global Concern}

Fire safety awareness can prevent fire incidents. Fire safety is often the content of many conversations and dialogues, both on the internet and in newspaper articles. These topics hint at the importance of knowing and understanding the dangers of home fires. The subsequent paragraphs usher the different awareness and strategies in preventing and fighting the fire in the international, national, and local scenes, not only by the firefighting bureaus but also by other sectors.

In Austin, the University of Texas has a Fire Prevention Service department that offers fire safety awareness. It discusses escape plans, smoke alarms, candles and incense, cooking, smoking, electricity, extension cords, and surge and suppressers, heating, laundry, fueling, and handling gasoline, and propane safety basics (University of Texas, Austin, 2018). In New Jersey, the essentials of checking a smoke alarm and regularly practicing a fire escape plan have become a routine considering that residents whose house catches fire have as little as two minutes to escape (United Ways of New Jersey, 2018). Hence, the urgency of fire awareness and prevention necessitates the installation of smoke alarms on every part and level of the home and testing them every month. Changing batteries that are not working and practicing the exit plan at least twice a year is also necessary. Notably, the American Red Cross (ARC) advises that if a fire occurs in the home, residents must immediately go out and call for help, never go 
back inside the house for anything or anyone to prevent loss of lives (The American National Red Cross, 2018).

Parenthetically, home fires can result in loss of properties and death. However, communities can prevent these if residents understand heat hazards, electrical hazards, general housekeeping hazards, smoking hazards, kitchen hazards, and fire safety in general (Fairfax County Fire and Rescue Department, 2007; Federal Emergency Management Agency, 2018; Philippine Primer, 2018; The American National Red Cross, 2018). Neckerman Insurance Services (2017) declared that space heaters accounted for one-third of fires from 2007 to 2011. In the Philippines, open flames from unattended stoves, faulty electrical connections, and lit cigarette butts are the top three causes of fire incidents (ABS-CBN News, 2018). In America, faulty outlets and appliances, light fixtures, extension cords, space heaters, and wirings are also the common causes of fires (FireRescue1 Staff, 2018).

In the same vein, the Tri-Star Insurance Professionals (2017) asserts that kitchens remain one of the most dangerous rooms in most homes. The U.S. Fire Administration estimated 164,500 cooking fires in residential buildings each year in the United States. Thus, awareness of the various kitchen fire hazards can help keep the home and family safe. To ensure safety, people must know how to prevent and respond to any fire emergency (Washburn University, 2018).

\subsection{Intervention Program}

Intervention is a response to a targeted deficiency. Interventions may be in the form of a well-designed policy, improvements in the facilities, environment, promotion campaigns for health or safety. Usually, intervention programs encompass multiple strategies for a lasting effect (Wright, 2015).

Intervention programs are standard in output studies, such as evaluation studies in which the goal is to assess the impact of a particular policy. Unfortunately, intervention programs do not come easy. They are a product of rigorous research and investigation efforts; otherwise, they would again fail like the original program. Intervention designers make a careful selection of options from very few choices, usually from research findings. It is imperative to choose a doable intervention program with a high percentage of success projection (American Institutes for Research, 2020; AUSPELD, 2020).

\subsection{Theoretical Framework}

Primarily, this study has its support from Republic Act 9514 or the "Fire Code of the Philippines of 2008", particularly the enforcement and adherence of standard fire prevention and safety measures (Republic Act No. 9514). The "hazardbarrier-target model" developed by William Haddon Jr. (Haddon, 1973) also became the anchor for this study. The "hazard-barrier-target model" is a systematic integration of risk reduction or accident reduction strategies. Hazard refers to a condition, or activity that can potentially cause harm or damage, including injuries to humans, damage to equipment, properties, or environment, or reduced ability to act as intended. Barrier refers to procedures that prevent undesired outcomes or reduce the likelihood of their occurrence, as well as maintaining the desired State. Target may be a person, object, or place selected as the aim of an attack.

In essence, the hazard-barrier-target model is a system safety assessment method that identifies hazards and evaluates controls that can prevent the event from occurring. The barrier approach expresses the system control with a hazardous energy source, potentially leading to damage, either to equipment or personnel (Haddon, 1970; Haddon, 1980).

From these premises came the safety theory, illustrated through a Swiss Cheese Model developed by Reason (1997). The basis of the safety theory was the impression that an approach of defense-in-depth can avoid accidents. Put differently, there is more than one barrier in a system, that may have faults and failures. The faults and failures in the barriers can cause the occurrence of untoward incidents. Reason illustrated this in an intuitive illustration of a "Swiss Cheese," where the cheese holes presented failure in the barrier and rightly called the Swiss Cheese Model. If the hazards transit through the holes (gaps), it can convert to either a severe incident or a system's failure. Reason also distinguished between terms (latent failure) and (active failure). Latent failure is a functional barrier failure due to unknown causes. It is not observable. Active failure, on the other hand, is an operational loss that occurs during the execution of barrier functions and is observable (Reason, 1997).

To illustrate the safety theory in the context of this study would give this perspective: the government prevents fire hazards by putting up barriers (fire code, fire safety inspections, etc.). However, if fires would still happen despite the measures in place, there is a system (organization) failure. In other words, whether or not the breakdown was latent or active, the system requires a study to introduce an intervention, overhauling, or altogether dismantling to give way to a new system, depending on the finding of the study.

Another useful theory for this study was the Protection Motivation Theory (PMT) developed by Rogers (1975). Roger's goal was to describe man's motivation to react to protect himself from any perceived health threat. This study contextualizes PMT as the building owners' motivation to comply with the building standards to avoid the impending dangers of fires resultant from non-compliance with the building code (Rogers, 1975).

\section{METHODOLOGY}

\subsection{Research Design}

This study is univariate, quantitative, and non-experimental research that employed a descriptive survey method. By univariate, it means that the investigation has only one variable. A univariate study does not deal with causes or 
relationships, and its central purpose is to describe the data, summarize the data, and finds patterns in the data (Canova, Cortinovis, \& Ambrogi, 2017). Quantitative means that the study used descriptive statistics in analyzing the data, utilizing percentages to compare the data (Kenton, 2019; Minitab Express, 2019).

Moreover, by non-experimental, it means that the study did not involve any control or experimental groups as sources of data. There was no use of a laboratory but used only survey instruments to collect the data (Punch, 2013). This study, however, used the secondary data available in the office of the Bureau of Fire Protection in Davao City from 2016 to 2018. The study's result would be the basis for proposing intervention strategies to prevent fire in homes and the community.

\section{Data Source}

This study utilized secondary data that comprised the consolidated accomplishment report on fire safety evaluation and inspection by the fire stations in Davao City from 2016 to 2018. The data included building structures such as the places of assembly, educational, health care, residential, mercantile, business, industrial, storage, mixed, and miscellaneous structures that are privately-owned or government-owned. The data for 2019 was not yet complete, thus, excluded.

\section{RESULTS}

\subsection{Comparative Data on the Application for Fire Safety Inspection Certificate from 2016 to 2018}

Shown in Table 1 is the three-year data on the application for a fire safety inspection certificate in Davao City from 2016 to 2018. These were those who applied for the Fire Safety Inspection Certificate (FSIC) as a requirement for an occupancy permit, business or permit to operate from 2016 to 2018. There were at least ten types of structures submitted for inspection. These include assembly, educational buildings, health care buildings, detention and corrections, residential buildings, mercantile structures, business structures, industrial buildings, storage facilities, and miscellaneous structures.

Table 1: Comparative Data on the Application for Fire Safety Inspection Certificate from 2016 to 2018

\begin{tabular}{|c|c|c|c|c|c|c|c|c|}
\hline $\begin{array}{c}\text { Applicatio } \\
\text { n for FSIC } \\
\text { (Structural } \\
\text { ) }\end{array}$ & $\begin{array}{c}201 \\
6\end{array}$ & $\%$ & $\begin{array}{c}201 \\
7\end{array}$ & $\%$ & $\begin{array}{c}201 \\
8\end{array}$ & $\%$ & Total & $\%$ \\
\hline $\begin{array}{c}\text { Places of } \\
\text { Assembly }\end{array}$ & 650 & 1.72 & 716 & 1.78 & 629 & 1.70 & 1995 & 1.74 \\
\hline $\begin{array}{c}\text { Education } \\
\text { al } \\
\text { Structures }\end{array}$ & 418 & 1.11 & 396 & 0.99 & 434 & 1.17 & 1248 & 1.09 \\
\hline $\begin{array}{c}\text { Health } \\
\text { Care } \\
\text { Structures }\end{array}$ & 219 & 0.58 & 216 & 0.54 & 156 & 0.42 & 591 & 0.51 \\
\hline $\begin{array}{c}\text { Detention } \\
\& \\
\text { Correction } \\
\text { al }\end{array}$ & 17 & 0.05 & 14 & 0.03 & 4 & 0.01 & 35 & 0.03 \\
\hline Residentia & 125 & 3.34 & 160 & 4.00 & 123 & 3.32 & 4095 & 3.57 \\
\hline
\end{tabular}

\begin{tabular}{|c|c|c|c|c|c|c|c|c|}
\hline $\begin{array}{c}1 \\
\text { Structures }\end{array}$ & 9 & & 6 & & 0 & & & \\
\hline $\begin{array}{c}\text { Mercantile } \\
\text { Structures }\end{array}$ & $\begin{array}{c}173 \\
81\end{array}$ & $\begin{array}{c}46.1 \\
3\end{array}$ & $\begin{array}{c}183 \\
64\end{array}$ & $\begin{array}{c}45.7 \\
4\end{array}$ & $\begin{array}{c}142 \\
76\end{array}$ & $\begin{array}{c}38.5 \\
7\end{array}$ & $\begin{array}{c}5002 \\
1\end{array}$ & $\begin{array}{c}43.5 \\
6\end{array}$ \\
\hline $\begin{array}{c}\text { Business } \\
\text { Structures }\end{array}$ & $\begin{array}{c}157 \\
03\end{array}$ & $\begin{array}{c}41.6 \\
7\end{array}$ & $\begin{array}{c}169 \\
62\end{array}$ & $\begin{array}{c}42.2 \\
5\end{array}$ & $\begin{array}{c}186 \\
91\end{array}$ & $\begin{array}{c}50.5 \\
0\end{array}$ & $\begin{array}{c}5135 \\
6\end{array}$ & $\begin{array}{c}44.7 \\
2\end{array}$ \\
\hline $\begin{array}{c}\text { Industrial } \\
\text { Structures }\end{array}$ & $\begin{array}{c}126 \\
1\end{array}$ & 3.35 & $\begin{array}{c}120 \\
9\end{array}$ & 3.01 & 923 & 2.49 & 3393 & 2.95 \\
\hline $\begin{array}{c}\text { Storage } \\
\text { Structures }\end{array}$ & 528 & 1.40 & 536 & 1.34 & 542 & 1.46 & 1606 & 1.40 \\
\hline $\begin{array}{c}\text { Miscellan } \\
\text { eous } \\
\text { Structures }\end{array}$ & 246 & 0.65 & 130 & 0.32 & 126 & 0.34 & 502 & 0.44 \\
\hline Total & $\begin{array}{c}376 \\
82\end{array}$ & $\begin{array}{c}100 . \\
00\end{array}$ & $\begin{array}{c}401 \\
49\end{array}$ & $\begin{array}{c}100 . \\
00\end{array}$ & $\begin{array}{c}370 \\
11\end{array}$ & $\begin{array}{c}100 . \\
00\end{array}$ & $\begin{array}{c}1148 \\
42\end{array}$ & $\begin{array}{c}100 . \\
00\end{array}$ \\
\hline
\end{tabular}

The data showed 114,842 structures inspected by the Bureau of Fire Protection in Davao City from 2016 to 2018. In 2016, the number of structures inspected was $37,682(32.81 \%)$. It increased to 40,149 (34.96\%) in 2017 and decreased to 37,011 $(32.23 \%)$ in 2018. By looking closely at the data, one could see that four structures comprised the biggest number of inspection applications for three consecutive years. These were the business structures $(51,365$ or $44.73 \%)$, mercantile structures $(50,021$ or $43.56 \%)$, residential structures $(4,095$ or $3.57 \%)$, and industrial structures (3,393 or $2.95 \%)$.

Conversely, the lowest total number of fire safety inspection applications belonged to detention and correctional facilities (35 or $0.03 \%$ ), then the miscellaneous structures $(0.44 \%)$, and the health care structures with $591(0.51 \%)$. Moreover, the places of assembly, storage structures, and educational structures had a respective total of $1995(1.74 \%), 1606$ $(1.40 \%)$, and $(1.12 \%)$ for three years.

By comparing the data by year, it showed an increasing number of Fire Safety Inspection Certificate applications for business structures for the three consecutive years, in 2016 $(15,703$, or $41.67 \%)$, in 2017 (16, 962, or 42.25\%), and 2018 $(18,691$, or $50.50 \%)$. However, for the mercantile structures, it had a total of 17,381 (46.13\%) FSIC applications in 2016. That number rose to $18,364(45.74 \%)$ in 2017 , but went down to $14,276(38.57 \%)$ in 2018.

The FSIC applications for residential structures increased by $.66 \%$ in 2017 (1606 or $4.00 \%$ ) from 1259 (3.34\%) but went down in 2018 by $.68 \%$ (1230 or $3.32 \%$ ). As for the industrial structures, it had a downward trend. In 2016 it had 1,261 (or $3.35 \%$ ) FSIC applications but it went in 2017 with 1209 (or $3.01 \%$ ), and further down in 2018 with only 923 (or 2.49\%) FSIC applications.

These data showed an erratic up-and-down pattern. The ideal way should be upward movement with an increasing number of FSIC applications every following year. Those that have applied the previous year should get another FSIC the next year, plus the new applications. However, these data implied that many of those with FSICs the last year did not renew the following year. 
In other words, only those owners of buildings with more significant capital expenditures strived to meet the fire code requirements because their facilities would not qualify for insurance coverage if they could not get a Fire Safety Inspection Certificate. Further, the data conveyed that the magnitude of capital investments is the right motivation for compliance with standards, which is the Philippines' fire code.

\subsection{Comparative Data on the Issuance of Fire Safety} Inspection Certificate (FSIC) from 2016 to 2018

Table 2 contains the data on the percentage of issuances of the fire safety inspection certificate (FSIC) in Davao City from 2016 to 2018. Table 2 reveals a total of 80.75 FSIC percent issuance rate from 2016 to 2018. The lowest is in 2018 at 76.19 percent. Moreover, a sloping trend for the three years was notable. In 2016, the issuance rate was practically high at 83.53 percent $(31,477)$. It decreased by 1.18 percent the following year (2017) and went down again by 6.16 percent the next year (2018).

Table 2: Comparative Data on the Issuance of Fire Safety Inspection Certificate from 2016 to 2018

\begin{tabular}{|c|c|c|c|c|c|}
\hline Year & $\begin{array}{c}\text { Applied } \\
\text { for } \\
\text { FSIC }\end{array}$ & $\begin{array}{c}\text { Issued } \\
\text { with } \\
\text { FSIC }\end{array}$ & $\begin{array}{c}\text { Difference } \\
\text { (Applied- } \\
\text { Issued) }\end{array}$ & $\begin{array}{c}\text { Percentage } \\
\text { of Issuance }\end{array}$ & $\begin{array}{c}\% \text { of Not } \\
\text { Complied/ } \\
\text { Not Issued } \\
\text { with FSIC }\end{array}$ \\
\hline 2016 & 37,682 & 31,477 & 6205 & 83.53 & 16.47 \\
\hline 2017 & 40,149 & 33,062 & 7087 & 82.35 & 17.65 \\
\hline 2018 & 37,011 & 28,198 & 8813 & 76.19 & 23.81 \\
\hline Total & 114,842 & 92,737 & 22105 & 80.75 & 19.25 \\
\hline
\end{tabular}

Obviously, there was a yearly percentage increase of those not issued with the fire safety compliance certificate from 2016 to 2018. The data in the table showed that from the year 2016, those not given with FSIC was 16.47 percent. It increased to 17.65 percent in 2017 and 23.81 percent in 2018.

The data conveyed that not all applications for FSIC were successful. The Bureau of Fire Protection (BFP) had turned down some applications for not satisfying the requirement stipulated in Republic Act No. 9514, otherwise known as the Fire Code of the Philippines of 2008.

\subsection{Intervention Strategies}

Since this study aimed to propose an intervention strategy based on the study's findings, the researcher presents the following key result areas, objectives, techniques, and means of verification. Persons responsible for are the BFP personnel. The source of funds is the BFP funds or budget.

First, systems upgradel updates in FSIC applications. Applying for FSIC is not easy, especially if building owners have to line up in the office. Sometimes, queues are long, and it would take them hours to wait. Sometimes, it would take days to finish the transaction, which is inconvenient on their part. Once the systems upgrade is in-placed, the application for FSIC will be online. This will facilitate easy transactions that could encourage more building owners to apply for a fire safety inspection.

Second, economic incentives to large companies. The agency may offer economic incentives to large companies that have maintained the fire suppressive system for three consecutive years. They may be given an automatic renewal of the FSIC. In this way, they will be free from the burden of securing new documents. With this strategy, large companies will be motivated to monitor their building's fire suppressive system, thus preventing fire incidents.

Third, imposing the penalties stipulated in the fire building code for violators. It is important to put teeth in implementing RA 9514. Oftentimes, those who were not granted the FSIC still continue with their building constructions, and operate their business. The BFP should strictly enforce the law to violators. Penalties should be imposed both to the building owner and the BFP inspector that circumvents the law. This will discourage people from executing malicious transactions, and corruption. Penalties for violating the code are already laid down in Section 11 of Republic Act No. 9514 against the private individual, and against the public officer or employee of the BFP. Therefore, penalties just have to be implemented to prevent people from violating the Fire Code. It is time for the BFP and the courts to be serious in implementing their mandates for the safety and security of communities.

Fourth, enhance the awareness of the public on fire safety and compliance. Fire safety is not exclusive for building owners but the public as well. Therefore, it is important to enhance the knowledge of the public on fire safety and compliance of RA 9514. Besides the fire drills that are conducted annually, the BFP can collaborate with the schools for an information drive by conducting lectures, symposia, and film viewings that would convey the dreadful message of fire and how fire incidents can be avoided. This will educate the public on fire safety in the homes and in the workplace.

Finally, regular inspection of communities prone to fires (esp. informal settlers). It is imperative that the BFP should conduct inspections on communities that are considered fire-hazard. To do that, they shall create a road map for the demolition of fire hazards to avoid the incidents of fire. The BFP shall coordinate with the LGUs for this operation to take place.

\begin{tabular}{|c|c|c|c|}
\hline $\begin{array}{c}\text { Key Result } \\
\text { Area }\end{array}$ & Objectives & Strategies & $\begin{array}{c}\text { Means of } \\
\text { Verification }\end{array}$ \\
\hline $\begin{array}{c}\text { Systems } \\
\text { upgrade/ } \\
\begin{array}{c}\text { FSIC } \\
\text { applications }\end{array}\end{array}$ & $\begin{array}{c}\text { To facilitate } \\
\text { an easy } \\
\text { FSIC } \\
\text { application } \\
\text { transaction }\end{array}$ & $\begin{array}{c}\text { To offer an online } \\
\text { application and } \\
\text { approval of FSIC, } \\
\text { both for new } \\
\text { application and } \\
\text { renewal }\end{array}$ & $\begin{array}{c}\text { Upgrade/up } \\
\text { dated } \\
\text { system }\end{array}$ \\
$\begin{array}{c}\text { Economic } \\
\text { incentives to } \\
\text { large } \\
\text { companies }\end{array}$ & $\begin{array}{c}\text { To } \\
\text { encourage } \\
\text { building } \\
\text { owners to } \\
\text { monitor and } \\
\text { maintain the }\end{array}$ & $\begin{array}{c}\text { To grant automatic } \\
\text { renewal of FSIC for } \\
\text { properly maintained } \\
\text { buildings with a fire } \\
\text { suppressive system } \\
\text { for three consecutive }\end{array}$ & $\begin{array}{c}\text { FSIC for } \\
\text { three } \\
\text { consecutive } \\
\text { years }\end{array}$ \\
\hline
\end{tabular}




\begin{tabular}{|c|c|c|c|}
\hline & $\begin{array}{l}\text { fire safety } \\
\text { of the } \\
\text { building }\end{array}$ & years & \\
\hline $\begin{array}{l}\text { Impose the } \\
\text { penalties } \\
\text { stipulated in } \\
\text { the fire } \\
\text { building code } \\
\text { for violators }\end{array}$ & $\begin{array}{l}\text { To compel } \\
\text { building } \\
\text { structure } \\
\text { owners to } \\
\text { follow the } \\
\text { law }\end{array}$ & $\begin{array}{l}\text { To padlock or close } \\
\text { buildings for } \\
\text { operations }\end{array}$ & Data logs \\
\hline $\begin{array}{l}\text { Enhance the } \\
\text { awareness of } \\
\text { the public on } \\
\text { fire safety } \\
\text { and } \\
\text { compliance }\end{array}$ & $\begin{array}{l}\text { To } \\
\text { disseminate } \\
\text { information } \\
\text { about fire } \\
\text { safety and } \\
\text { the dangers } \\
\text { of fires }\end{array}$ & $\begin{array}{l}\text { To collaborate with } \\
\text { schools for the } \\
\text { conduct of lectures, } \\
\text { film viewings, } \\
\text { symposiums, with } \\
\text { fire drill as the } \\
\text { concluding activity }\end{array}$ & $\begin{array}{l}\text { MOA/MO } \\
\text { U with } \\
\text { schools } \\
\text { Documenta } \\
\text { tion during } \\
\text { the } \\
\text { activities } \\
\text { Attendance } \\
\text { sheets } \\
\text { during the } \\
\text { activity }\end{array}$ \\
\hline $\begin{array}{l}\text { Regular } \\
\text { inspection of } \\
\text { communities } \\
\text { prone to fires } \\
\text { (esp. } \\
\text { informal } \\
\text { settlers) }\end{array}$ & $\begin{array}{l}\text { To create a } \\
\text { roadmap for } \\
\text { the } \\
\text { demolition } \\
\text { of fire } \\
\text { hazards }\end{array}$ & $\begin{array}{l}\text { To collaborate with } \\
\text { government agencies } \\
\text { responsible for } \\
\text { relocation and } \\
\text { demolition of } \\
\text { informal settlers. }\end{array}$ & $\begin{array}{c}\text { Memos } \\
\text { Agreements } \\
\text { Other } \\
\text { documents }\end{array}$ \\
\hline
\end{tabular}

\section{DISCUSSION, CONCLUSION AND RECOMMENDATIONS}

\subsection{Comparative Data on the Application for Fire Safety Inspection Certificate from 2016 to 2018}

The 2016 to 2018 data on the application for fire safety inspection certificate has an irregular up-and-down pattern. This pattern is opposed to the expected upward movement yearly. The rationale of the increasing trend is that every year, all FSICs of business establishments and other building structures should be renewed. Therefore, the it is expected that there will be an increase of FSIC applications every year with the addition of the new applications. The finding in this study of an up-and down pattern in the application of FSIC suggested that more and more building owners have not complied the FSIC, whether renewal or new application. This means that percentage of compliance of the fire code of the Philippines, which set the building standards of the country (Republic Act 9514) was low. These buildings include places of assembly, educational buildings, health care buildings, detention and correctional facilities, residential buildings, mercantile structures, business structures, industrial buildings, storage facilities, mixed occupancy buildings, and miscellaneous structures.

Sadly, the low percentage of compliance on fire safety is evident in not only private edifices but also the government buildings such as schools, health care buildings, and detention and correctional facilities. The government should have been the first, among others, when it comes to compliance of standards (National Fire Protection Association, 2019; Rey, 2017), as no one is above the law.

Compliance with the fire code is important because it advocated the fire safety of buildings, which, when neglected can affect thousands of companies and lives resulting from fire incidents. On many occasions, lives of peple and properties were lost to the neglect of fire safety. In Davao City alone, fire incidents rose by 32.1 percent (416 cases) from 2017 to 2018. Most of these fire incidents occurred in urban residential areas caused by electrical short circuit, arcing due to lose connections, overheated electrical appliances, unattended cooking, child playing lighted matchsticks or candles. In 2017, the total damage of properties reached to P2,285,891,195 because big business establishments were also razed by fire (NDRRMC, 2017; Revita, 2019). To add to that, on December 23, 2017, a fire at the New City Commercial Center (NCCC) mall in Davao City claimed the lives of at least thirty-eight people, probably caused by faulty electrical wiring due to a renovation malpractice (Antonio IV, 2018; Basa, 2017; Nawal \& Lim, 2017; Villamor, 2017a; 2017b).

These incidents are not only happening in the Philippines but also in other parts of the world. For example, in Australia, a fire broke out on August 30, 2018 in a large warehouse in West Footscray, in Melbourne. It took the Metropolitan Fire Brigade (MFB) 14 hours to bring under control and several days to extinguish (Australian Institute for Disaster Resilience, 2019).

Because of these incidents, countries all over the world are setting up measures to prevent these from occurring. In America, for example, the U. S. Fire Administration (USFA) has developed the fire prevention and safety education programs, which they collaborated with other federal agencies such as the fire and emergency response community, the media, and safety interest groups. They also collaborated with public and private institutions for the promotion of fire prevention and life safety through research and testing (Federal Emergency Management Agency, 2018).

Likewise, in the Philippines, the Bureau of Fire Protection also launched fire awareness programs all over the country to reduce the number of fire incidents, as well as fire drills to mitigate injuries due to blaze (Opiana, 2017). However, even with these measures, incidents of fire are still widespread in the country because of non-compliance or poor compliance of the fire code by building owners (Dalumpines, 2019).

\subsection{Comparative Data on the Issuance of Fire Safety Inspection Certificate (FSIC) from 2016 to 2018}

The percentage of issuance of fire safety inspection certificate (FSIC) was in a decreasing trend from 2016 to 2018. Based on the data gathered from the BFP, not all building owners who applied for inspection were issued the FSIC. Those who have satisfactorily complied with the fire safety requirements were given the FSI certificate. Those who failed to submit the requirements on time were given "pending" remarks. Buildings that were not compliant of the fire code were closed 
either on a temporary period pending compliance or were permanently closed due to their irreparable state or the imminent danger they posed (Bureau of Fire Protection, 2018).

In addition, this study found that only mercantile, business, and industrial buildings have high percentages of FSIC issuance. Predictably, owners of these buildings understood the risks of not following the fire safety standards. Owners of big buildings have more to lose from fire, thus, they tend to comply with the fire code, although not all (Evac Group, 2019; Stevens \& Bolton, 2012).

Accordingly, fire safety inspection happens before, during and after the construction of the building. The Fire Safety Inspection Certificate (FSIC) is a prerequisite for the business or occupancy permit. The owner of the building secures the FSIC at least once every year to continue occupying the building or to renew the business permit to operate (RA 9514).

The data on the issuance of FSIC revealed that owners of other types of buildings or occupancies do not comply with the fire code given the very small number of those that comply. This situation compromises the safety of communities against fire incidents. Fire safety should be everyone's concern, whether at home or elsewhere. No less than Secretary Año urged the public to be observe fire safety as it not the sole responsibility of the bureau (Department of the Interior and Local Government, 2018). Moreover, the Bureau of Fire Protection designated the month of March as the fire prevention month in the Philippines because a lot of fire incidents happened during this month, especially those fire incidents that started in the homes. The BFP introduced innovative programs to promote fire safety in the homes (Department of the Interior and Local Government, 2020).

Furthermore, the downward trend in the issuance of the FSIC from 2016 to 2018 conveyed that less and less of the building owners have applied for business permits. With the numerous buildings built every year, it can be surmised that some buildings are illegally erected (Philippine Statistics Authority, 2019; 2020).

In other words, the data implies defects in the building inspection processes as owners still got to construct the building even without complying with the requirements and then occupying the building afterwards (Rey, 2017). There may be corruption in the processes. Even with the internal cleansing professed by the leaders of the agency, still corruption is evident in the bureau (Colina, 2018). Lawmakers sought for a corruption-free inspection of buildings owing the several damages of buildings during calamities, not only from fire but also from earthquakes (Pacpaco, 2019). Not only that, the BFP came up with the integrity poster for anti-graft and corruption drive of the BFP (Bureau of Fire Protection, 2018), which indicates that corruption is still happening in the bureau.
In the light of the NCCC fire incident that killed 38 people, the BFP 11 Regional Director has admitted that corruption exists in the bureau and that corruption is not only happening in his region but that it is a nationwide phenomenon (Colina, 2018). If this continues to be the trend all through the years, then, even the owners of big buildings who tried to be compliant with the RA 9514 will eventually join the bandwagon that would put the whole country at risk of being razed to the ground.

\subsection{Conclusion}

The downward percentage compliance of the Fire Code by Davao City residents denotes that the city is at a higher risk of fire incidence. The data from the Bureau of Fire in Davao City did not specify whether those that did not comply with the fire safety have not actually used or occupied the building. Likewise, the decreasing percentage of issuance of the fire safety inspection certificates (FSIC) suggests that the some personnel in the bureau have implemented the fire code by meticulously inspecting the structures and refusing to issue FSIC to those who have not outstandingly complied with the fire code requirements. However, the several buildings erected without the building permits, may mean that corruptions in the bureau, (as what authorities have pointed out) still exist.

The result affirms the theoretical underpinnings of this study, nemly the "hazard-barrier-target model" developed by William Haddon Jr. (Haddon, 1973), the safety theory, illustrated through a Swiss Cheese Model developed by Reason (1997), and the Protection Motivation Theory (PMT) developed by Rogers (1975). The study concludes that barriers, like RA 9514, has a lot of gaps, such as the implementation loopholes that cause the system to fail. The result of this study has great implications to the BFP as a protection bureau.

\subsection{Recommendations}

In view of the findings of the study, the researcher has proposed for intervention strategies that may be adopted by the Bureau of Fire Protection (BFP) to ensure compliance of the fire code and uphold fire safety in the homes and the entire community. The researcher strongly suggest for the implementation of the proposed strategies presented in this paper. Importantly, in the light of the results and conclusions of the study, the researcher suggests that stringent penalties may be imposed to erring BFP officials and the non-compliant building owners.

\subsection{Suggestion for Future Studies}

Furthemore, the researcher suggests for other types of research to be conducted, such as the exploratory factor analysis (EFA), to look into the reasons why some structure owners do not comply with the fire code. Findings of the EFA study may be used as basis for a policy review. 


\section{REFERENCES}

[1] ABS-CBN News. (2018). In the know: The top 3 causes of fire in P.H. Retrieved August 5, 2018, from https://news.abscbn.com/news/03/01/18/in-the-know-the-top-3-causes-of-fire-inph

[2] American Institutes for Research. (2020). Validated Intervention Program | National Center on Intensive Intervention. Intensiveintervention.org.

https://intensiveintervention.org/intensive-intervention/

[3] American Red Cross. (2019). What is the home fire campaign? Retrieved from https://www.redcross.org/get-help/how-to-preparefor-emergencies/types-of-emergencies/fire/prevent-home-fire.html

[4] Antonio IV, C. (2018). NCCC mall fire a year later: reckless imprudence charges vs NCCC, SSI dropped. Retrieved from https://www.mindanews.com/top-stories/2018/12/nccc-mall-fire-ayear-later-reckless-imprudence-charges-vs-nccc-ssi-dropped/

[5] AUSPELD. (2020). Selecting a successful intervention program. The Australian Federation of SPELD Associations. https://uldforparents.com/contents/selecting-a-successfulintervention-program/

[6] Australian Building Codes Board. (2019). Energy efficiency NCC 2022 and beyond scoping study. Retrieved from https://consultation.abcb.gov.au/engagement/energy-efficiencyscoping-study-2019/

[7] Australian Institute for Disaster Resilience. (2019). Major incidents report 2018-2019. Warehouse fires Victoria, August 2018 and April 2019. Retrieved from https://www.aidr.org.au/media/7087/aidr_major-incidentsreport_web_2019-08-22.pdf

[8] Basa, M. (2017). 36 bodies found inside Davao City mall. Retrieved form https://www.rappler.com/nation/192232-bodiesfound-davao-nccc-mall-fire

[9] Bautista, M. F. (2017). Consolidated fire incidents in Metro Manila. Retrieved from http://www.asppi.org.ph/files/public/publication/Consolidated $\% 20$ Fire\%20Incident\%20in\%20Metro\%20\%20Manila\%20OSCH.pdf

[10] Bureau of Fire Protection (BFP). (2018). Integrity poster for antigraft and corruption drive of the BFP. Retrieved from http://bfp.gov.ph/integrity-poster-for-anti-graft-and-corruptiondrive-of-the-bfp/\#.XkAT5uMzbIU

[11] Canova, S., Cortinovis, D. L., and Ambrogi, F. (2017). How to describe a univariate data. Retrieved September 10, 2018, from Journal of Thoracic Disease, 9 (6), pp. 1741-1743. doi: $10.21037 /$ jtd.2017.05.80

[12] CFPE Europe. (2019). Description of the national fire regulation framework for buildings. Retrieved from http://cfpa-e.eu/nationalregulations/regulations-france/

[13] Colina, A. IV. (2018). 33 individuals may face charges due to NCCC mall fire. Retrieved July 5, 2018, https://news.mb.com.ph/2018/06/08/33-individuals-may-facecharges-due-to-nccc-mall-fire/

[14] Dalumpines, J. (2019). 439 fire incidents in Davao City this year. Retrieved from https://pia.gov.ph/news/articles/1031199

[15] Department of the Interior and Local Government. (2018). Año to public: Fire safety is every Filipino's responsibility. Retrieved from https://dilg.gov.ph/news/Ao-to-public-Fire-safety-is-everyFilipinos-responsibility/NC-2018-1036

[16] Department of the Interior and Local Government. (2020). Fire Prevention Month. Retrieved from https://dilg.gov.ph/events/FirePrevention-Month/633DILG

[17] Evac Group. (2019). Emergency planning: Consequences of noncompliance. Retrieved from https://www.evacservices.com.au/consequences-non-compliance/

[18] Fairfax County Fire and Rescue Department. (2007). Home fire safety survey. Retrieved July 10, 2018, from https://www.fairfaxcounty.gov/fire-ems/sites/fireems/files/assets/documents/pdf/obeythelaw.pdf

[19] Federal Emergency Management Agency (FEMA). (2018). Fire prevention and public education. Retrieved July 5, 2018, from https://www.usfa.fema.gov/prevention/
[20] FireRescue1 Staff. (2018). Five common causes of electrical fires. Retrieved August 5, 2018, from https://www.firerescue1.com/fireproducts/fire-safety-for-children/articles/1206100-5-commoncauses-of-electrical-fires/

[21] Fire Risk U.K. Limited, (2018). Theory of fire. Retrieved August 5, 2018,from https://fireriskuk.com/training/theory_of_fire.htm

[22] Government of Australia. (2020). The building code of Australia. Retrieved from https://www.sa.gov.au/topics/planning-andproperty/land-and-property-development/building-rulesregulations-and-information/the-building-code-of-australia

[23] Government of Canada. (2019). National Fire Code of Canada 2015. Retrieved from https://nrc.canada.ca/en/certificationsevaluations-standards/codes-canada/codes-canadapublications/national-fire-code-canada-2015

[24] Haddon, W. (1970). On the escape of tigers: An ecological note. Technological review, 72(7), Massachusetts Institute of Technology.

[25] Haddon, W., Jr. (1973). Energy damage and the ten countermeasure strategies. Hum. Factors, 15, 355-366.

[26] Haddon, W. (1980). The basic strategies for reducing damage from hazards of all kinds. Hazard prevention, Sept/Oct. 1980.

[27] Kenton, W. (2019). Descriptive statistics. Retrieved from https://www.investopedia.com/terms/d/descriptive_statistics.asp

[28] London Fire Brigade. (2019). The Regulatory Reform (Fire Safety) Order 2005, England and Wales. Retrieved from https://www.london-fire.gov.uk/safety/the-workplace/fire-safetylaw-explained/

[29] Mayuga, J. L. (2018). Tragedy of fires: Death and destruction in the Philippines. Retrieved July 5, 2018 from https://businessmirror.com.ph/tragedy-of-fires-death-anddestruction-in-the-philippines/

[30] Ministry of Business, Innovation, \& Employment. (2020). Building code compliance. Retrieved from https://www.building.govt.nz/building-code-compliance/

[31] Minitab Express (2019). What are inferential statistics? Retrieved from https://bit.ly/2tTeaeO

[32] Nawal, A. \& Lim, F. (2017). Mall worker brings to 38 the fatalities of Davao mall fire. Retrieved from https://newsinfo.inquirer.net/955459/mall-worker-brings-to-38 thefatalities-of-davao-mall-fire

[33] NDRRMC. (2017). Fire incident at Bankerohan, Davao City. Retrieved from http://ndrrmc.gov.ph/attachments/article/3252/UpdateIncidentMon itored06Dec2017.pdf

[34] National Fire Protection Association (NFPA). (2019). NFPA 1, Fire Code. Retrieved from https://www.nfpa.org/codes-andstandards/all-codes-and-standards/list-of-codes-andstandards/detail? code $=1$

[35] National Safety Council. (2018). Top Causes of Unintentional Injury and Death in Homes and Communities. Retrieved July 5, 2018, from https://www.nsc.org/home-safety

[36] National Safety Council. (2020). Top Causes of Preventable Injuries, Death Off the Job. Retrived from https://www.nsc.org/home-safety

[37] Neckerman Insurance Services. (2017). 6 Most Common Fire Hazards in the Home. Retrieved July 5, 2018, https://neckerman.com/6-most-common-fire-hazards-in-the-home/

[38] Opiana, J. A. (2017). BFP bares activities for Fire Prevention Month. Retrieved July 5, 2018, from http://edgedavao.net/the-bignews/2017/03/02/bfp-bares-activities-fire-prevention-month/

[39] Pacpaco, R. P. (2019). House leaders seek corruption-free building inspection. Retrieved from https://journal.com.ph/news/nation/house-leaders-seek-corruptionfree-building-inspection

[40] Philippine Primer. (2018). Fire Prevention Month: What to Do During a Fire. Retrieved July 5, 2018, from http://primer.com.ph/tips-guides/2018/03/22/fire-preventionmonth-what-to-do-during-a-fire/

[41] Philippine Statistics Authority. (2019). Construction Statistics from Approved Building Permits: Fourth Quarter 2019 (Preliminary Results). Retrieved from 
http://www.psa.gov.ph/content/construction-statistics-approvedbuilding-permits-fourth-quarter-2019-preliminary-results

[42] Philippine Statistics Authority. (2020). Construction Statistics from Approved Building Permits: First Quarter 2020. Retrieved from http://www.psa.gov.ph/content/construction-statisticsapproved-building-permits-first-quarter-2020

[43] Punch, K. F. (2013). Introduction to social research: Quantitative and qualitative approaches. Sage.

[44] Reason, J. (1997). Managing the risks of organizational accidents. Ashgate. http://tinyurl.com/nodbbov

[45] Republic Act No. 9514 | GOVPH. (2008, December 18). Official Gazette of the Republic of the Philippines. https://www.officialgazette.gov.ph/2008/12/19/republic-act-no9514/

[46] Revita, J. C. (2018). NCCC Mall fire report done. Retrieved July 5, 2018, from https://www.sunstar.com.ph/article/422125

[47] Revita, J. C. (2019). Davao City: Fire incidents up by $31.1 \%$. Retrieved from https://www.sunstar.com.ph/article/1781790

[48] Rey, A. (2017). Will you report corrupt fire bureau officials? Retrieved from https://www.rappler.com/move$\mathrm{ph} /$ issues/corruption/158232-fire-extinguishers-inspection-bfpcorruption

[49] Rogers, R. W. (1975). A protection motivation theory of fear appeals and attitude change. J Psychol. 91:93-114.

[50] Stevens \& Bolton. (2012). Fire safety the risks and costs of noncompliance with the regulations. Retrieved from https://www.stevens-bolton.com/cms/document/fire.pdf

[51] The American National Red Cross. (2018). Home Fire Safety. Retrieved September 18, 2018, from https://www.redcross.org/get- help/how-to-prepare-for-emergencies/types-ofemergencies/fire.html

52] Tri-Star Insurance Professionals. (2017). Oven and grill safety, microwave safety, and grease fire safety. Retrieved August 8, 2018, from https://tristarins.com/kitchen-fire-hazards-to-be-awareof/

[53] United Ways of New Jersey. (2018). Fire Safety Preparedness. Retrieved September 18, 2018, from https://www.nj211.org/firesafety-preparedness

[54] University of Texas, Austin. (2018). Fire Safety Awareness. Retrieved July $10, \quad 2018, \quad$ from https://fireprevention.utexas.edu/firesafety/fire-safety-awareness

[55] Villamor, F. (2017a). Fire traps dozens inside Philippines mall. Retrieved from https://www.nytimes.com/2017/12/24/world/asia/philippines-mallfire.html

[56] Villamor, F. (2017b). Fire traps dozens inside Philippines mall. Retrieved from https://www.smh.com.au/world/asia/fire-inphilippine-shopping-mall-kills-37-20171224-p4yy0x.html

[57] Washburn University. (2018). Fire and life safety guidelines. Retrieved August 8, 2018, from https://washburn.edu/parentsfamily/health-safety/safety-planning/fire-and-life-safetyguidlines.html

[58] William Hird \& Company. (2020). The importance of being up to local fire code standards. Retrieved from https://www.hirdco.com/fire-extinguishers/importance-local-firecode-standard/

[59] Wright, J. D. (2015). International encyclopedia of the social \& behavioral sciences. Reference work. (2nd edition). Elsevier. https://www.sciencedirect.com/referencework/9780080970875 